Pesq. Vet. Bras. 36(8):749-752, agosto 2016 DOI: $10.1590 / \mathrm{S} 0100-736 \mathrm{X} 2016000800012$

\title{
Gyrostigma rhinocerontis (Diptera: Oestridae, Gasterophilinae) in white rhinoceroses (Ceratotherium simum) imported from South Africa: occurrence in Itatiba, São Paulo, Brazil ${ }^{1}$
}

\author{
José R. Pachaly ${ }^{2,3 *}$, Luiz P.C. Monteiro-Filho³, Daniela D. Gonçalves² \\ and Evandra M. Voltarelli-Pachaly ${ }^{3}$
}

\begin{abstract}
Pachaly J.R., Monteiro-Filho L.P.C., Gonçalves D.D. \& Voltarelli-Pachaly E.M. 2016. Gyrostigma rhinocerontis (Diptera: Oestridae, Gasterophilinae) in white rhinoceroses (Ceratotherium simum) imported from South Africa: occurrence in Itatiba, São Paulo, Brazil. Pesquisa Veterinária Brasileira 36(8):749-752. Programa de Pós-Graduação em Ciência Animal com Ênfase em Produtos Bioativos, Universidade Paranaense, Praça Mascarenhas de Moraes 4282, Centro, Umuarama, PR 87502-210, Brazil. E-mail: pachaly@uol.com.br

Fly larvae from the Gasterophilinae subfamily of the Oestridae family are parasites of domestic (equine) and wild (rhinos and equine) odd-hoofed ungulates (Perissodactyla). The gastric parasite of African Rhinos is Gyrostigma rhinocerontis (formerly Gyrostigma pavesii), which in its larva phase can be found in the feces of their hosts and can reach $40 \mathrm{~mm}$ length. The adult is the largest fly in Africa, reaching $41 \mathrm{~mm}$ long, with 71-mm wingspan. The Gyrostigma genus does not occur naturally in Brazil. There is one previous report of the occurrence of its larvae in the feces of a white rhino brought from South Africa in the 1990 's, which was housed in a zoo located in Rio Grande do Sul. The present paper furnishes data from a zoo of the city of Itatiba, São Paulo state, Brazil, where Gyrostigma rhinocerontis larvae were found in 2005 in the feces of a group of white rhinos (Ceratotherium simum) legally imported from South Africa. The rhinos were kept in a breeding and preservation farm. This paper also reports the measures taken to control the case and avoid the dissemination of the parasite, calling attention to the fact of globalization, which allows international and intercontinental transit of wild animals with potential risks of adaptation of exotic parasites to new ecosystems.
\end{abstract}

INDEX TERMS: Gyrostigma rhinocerontis, Diptera, Oestridae, Gasterophilinae, white rhinoceros, Ceratotherium simum, wild animals, feces, flies, parasites, perissodactylids.

\begin{abstract}
RESUMO.- [Gyrostigma rhinocerontis (Diptera: Oestridae, Gasterophilinae) em rinocerontes-brancos (Ceratotherium simum) importados da África do Sul: ocorrência em Itatiba, São Paulo.] As larvas dos dípteros da subfamília Gasterophilinae da família Oestridae parasitam ungulados perissodáctilos, tanto domésticos (equídeos) quanto selvagens (rinocerontes e equídeos). 0 parasito

\footnotetext{
${ }^{1}$ Received on Setember 23, 2015.

Accepted for publication on May 7, 2016.

${ }^{2}$ Programa de Pós-Graduação em Ciência Animal com Ênfase em Produtos Bioativos, Universidade Paranaense (UNIPAR), Praça Mascarenhas de Moraes 4282, Centro, Umuarama, PR 87502-210, Brazil. *Corresponding author: pachaly@uol.com.br

${ }^{3}$ Instituto Brasileiro de Especialidades em Medicina Veterinária (EspecialVet), Rua Lopes Trovão 250, Zona 4, Maringá, PR 87014-080, Brazil.
}

gástrico dos rinocerontes africanos é Gyrostigma rhinocerontis (anteriormente Gyrostigma pavesii), que na fase larval pode ser encontrada nas fezes dos hospedeiros, e chega a medir $40 \mathrm{~mm}$ de comprimento. 0 adulto é a maior mosca daquele continente, atingindo até $41 \mathrm{~mm}$ de comprimento, e envergadura de $71 \mathrm{~mm}$. 0 gênero Gyrostigma não ocorre naturalmente no Brasil, onde anteriormente existia somente um relato do achado de larvas, nas fezes de um rinoceronte-branco oriundo da África do Sul nos anos 90 do século XX, e albergado num zoológico localizado no Rio Grande do Sul. Este artigo apresenta dados sobre o achado, em um zoológico no município de Itatiba, Estado de São Paulo, Brasil, de larvas de Gyrostigma rhinocerontis nas fezes de um grupo de rinocerontes-brancos (Ceratotherium simum) importados legalmente da África do Sul, onde eram manti- 
dos em uma fazenda de preservação com criação manejada, em 2005. São relatadas também as medidas tomadas para controle do caso e prevenção da disseminação do parasito, e se discutem os riscos da globalização, que viabiliza o trânsito internacional e intercontinental de animais selvagens, com riscos potenciais de adaptação de parasitos exóticos a novos ecossistemas.

TERMOS DE INDEXAÇÃO: Gyrostigma rhinocerontis, Diptera, Oestridae, Gasterophilinae, rinoceronte-branco, Ceratotherium simum, animais selvagens, fezes, moscas, parasitos, perissodátilos.

\section{INTRODUCTION}

There are five species of rhinos, two of them from Africa, the white rhino (Ceratotherium simum) and the black rhino (Diceros bicornis), and three from Asia, as the Indian rhino (Rhinoceros unicornis), the Javan rhino (Rhinoceros sondaicus) and the Sumatran rhino (Dicerorhinus sumatrensis) (Nelson \& Fowler 1986, Miller 2003). All these species suffer with a sharp population decrease, due to illegal poaching that aims to harvest their horns and other parts of the body, which have a high value for oriental traditional medicine (Miller 2003). The white rhino is the most numerous species, with about 10.000 animals, mainly concentrated in South Africa, a country that makes great efforts for its preservation (Miller 2003).

Similar to other large ungulate mammals, rhinos can be infected by a large variety of parasites of all kinds (Zumpt 1965, Silberman \& Fulton 1979, Griner 1983, Lang 1983, Nelson \& Fowler 1986, Ramsay \& Zainuddin 1993, Brum et al. 1996, Miller 2003, Gunn \& Pitt 2012).

Flies from the subfamily Gasterophilinae in the Oestridae family encompass the well-known "gastric botflies" Gasterophilus intestinalis, G. nasalis e G. hemorrhoidalis, which infect domestic horses, donkeys and mules. Other gasterophilidae infect wild perissodactiles in the Equidae (zebras) and Rhinocerotidae (rhinos) families, with host specificity. In all cases, the final larva stage is found inside the gastrointestinal tract, usually in the stomach (Gunn \& Pitt 2012).

According to Zumpt (1965), rhino stomachs can be parasitized by three Gasterophilinae species, all from the Gyrostigma genus - G. pavesii (currently G. rhinocerontis), G. conjungens and $G$. sumatrensis.

The Gyrostigma rhinocerontis species was described in the middle of the 19th Century, initially from larva found in rhino feces and in the gut of slaughtered animals (Zumpt 1965, Barraclough 2006), and it has raised several taxonomic controversies, being classified under several names and authors. The genus name was given by Brauer, in 1885, when describing Gyrostigma sumatrensis (Evenhuis 2012, NHM 2014). Currently, based on a series of evidence collected by Evenhuis (2012), the correct citation for the original description and listing prepared by Hope in 1940, is Gyrostigma rhinocerontis [Owen], 1930:143 (originally Oestrus rhinocerontis Owen, then Oestrus rhinocerontis Hope, and later Gyrostigma pavesii Corti). The author has rescued lost data that has been recently recovered, enabling the taxonomic classification to be as follows: Empire Eukaryota,
Kingdom Animalia, Phylum Arthropoda, Class Insecta, Order Diptera, Family Oestridae, Genus Gyrostigma, Species rhinocerontis (Evenhuis 2012, NHM 2014).

There are records of two other species in the Gyrostigma genus, G. conjungens (Africa) and G. sumatrensis (Sumatra Island, in Asia). Both are extremely rare, and may even be extinct. G. conjungens was last seen in 1961, and G. sumatrensis was recorded only once, in 1884, in the form of larva recovered from a Sumatran rhino (Dicerorhinus sumatrensis) in Hamburg zoo, in Germany, with no adult specimens known (Zumpt 1965, NHM 2014).

The white, oblong eggs from Gyrostigma rhinocerontis are laid on the rhino head, especially in its nostrils and next to the horn, hatching in approximately six days (Miller 2003, Barraclough 2006). The larvae measure approximate $25 \mathrm{~mm}$ and migrate until they reach the gastric mucosa by means of body spicules and oral hooks, feeding on blood and gastric tissue, going through three development stages (Barraclough 2006).

In the first development stage, the larvae have a dark pink color, penetrating deeply in the mucosal folds in the gastric lining. In the second stage, they measure approximately $2.0 \mathrm{~cm}$ and their color is light pink, the spicules are more prominent and the rostral end is inserted within the gastric folds. Finally, in the third stage, the mature larvae reach its definitive size, and are yellowish white with brown irregular spots. Their spicules form bands with three or four lines of spicules (Barraclough 2006, NHM 2014). The three slits in the posterior breathing spiracles of the larva in its third stage are long and tortuous, differing itself from the larvae from the two other Gyrostigma species, which have less tortuous slits (NHM 2014).

In the rhino stomach, a great amount of larvae in all development stages can be concomitantly found (Barraclough 2006). They are especially located in the esophageal region of the stomach, in the transition between the stratified squamous epithelium and the secretory columnar epithelium, but can also be seen in the glandular region of the organ, and eventually even in the lower portion of the esophagus (Silberman \& Fulton 1979).

When the larvae are ready for the pupal stage, they exit the stomach, transit through the digestion tract and leave the host's body through the anus (Barraclough 2006), and can be found in feces immediately after defecation. The pupae are not found in the feces of parasitized rhinos, since the manure and larvae tend to quickly abandon the fecal material, burying in the soil. The pupa phase lasts six weeks, and after it, the adult insect hatches (Barraclough 2006).

The adult Gyrostigma rhinocerontis is the largest fly in Africa, measuring between 35 and $41 \mathrm{~mm}$, with wingspan of up to $71 \mathrm{~mm}$, while the larvae can reach up to $40 \mathrm{~mm}$ (Barraclough 2006, Gunn \& Pitt 2012). Male and female adults have very similar morphology - the head ranges from orange-red to dark brown; the thorax from dark brown to black, with a lighter median strip, of variable width; the abdomen has similar color as the thorax, with a lighter, reddish end; the long wings go beyond the end of the abdomen when closed, ranging from dark brown to black; and 
the legs are reddish orange, long and slim (Barraclough 2006, Gunn \& Pitt 2012, NHM 2014). Its mouth apparatus is rudimentary, and the adults do not probably feed, which is coincident with the adults from Gasterophilus (Barraclough 2006, Gunn \& Pitt 2012, NHM 2014). The female specimens are active during the day, when they lay eggs on hosts, and the male are only active in the twilight hours of dusk and dawn, when they copulate. The adults fly for only three to five days, when they copulate, lay eggs and die (Barraclough 2006).

The aim of this paper is to rescue information on the finding, in a Brazilian zoo, of Gyrostigma rhinocerontis larvae (previously Gyrostigma pavesii) in the feces of white rhinos (Ceratotherium simum). It also reports the measures taken to control the case and avoid the dissemination of the parasite.

\section{MATERIALS AND METHODS}

The case occurred in a zoo located in the city of Itatiba, State of São Paulo, Brazil, where five specimens of white rhino (Ceratotherium simum) were received directly from South Africa on January 13,2005 , by means of legal importation. They were two male and three female young rhinos and upon arrival the smallest weighed approximately $500 \mathrm{~kg}$, and the largest weighed $800 \mathrm{~kg}$. The animals were all originated from the same managed-breeding preservation farm located in an environmental reserve, and participating in a project accomplished with the participation of the South-African government, which allows the trading of a percentage of born individuals to be used in the efforts of reproduction for preservation.

The rhinos were kept together, going through an acclimatization and adaptation period in an enclosure specially designed for them, and in the first 92 days in the zoo, they were in strict quarantine, being daily monitored by a veterinarian, biologists and zookeepers.

Large diptera larvae, some measuring up to $4.72 \mathrm{~cm}$ in length and $2.18 \mathrm{~cm}$ in diameter, were found in feces collected from the floor of the quarantine enclosure on February 8, 2005, 23 days after the animals arrived in Brazil. Immediately the team has taken measures to identify and control the parasite, considered exotic to Brazil and thus potentially dangerous.

As part of the management duties the feces were systematically removed from the enclosure in a 24-48 hour basis, and the search for larvae followed this routine during the period of study and the following two years.

\section{RESULTS AND DISCUSSION}

The observed larvae were identified as Gyrostigma rhinocerontis (Diptera: Oestridae, Gasterophilinae), by morphologic evaluation and literature review (Fig.1) (Evenhuis 2012, Gunn \& Pitt 2012, NHM 2014). The paper from Evenhuis (2012) brings a careful description of all development stages of $G$. rhinocerontis and contains some of the original drawings prepared by the first researchers who studied this fly in the early decades of 1800 years, and this recently published text was decisive for correct identification of the larvae.

There are many references to the finding of Gyrostigma rhinocerontis larvae, which are frequently found in the stomach of both African rhino species (Lang 1983, Ramsay \& Zainuddin 1993), and Miller (2003) mentions that they
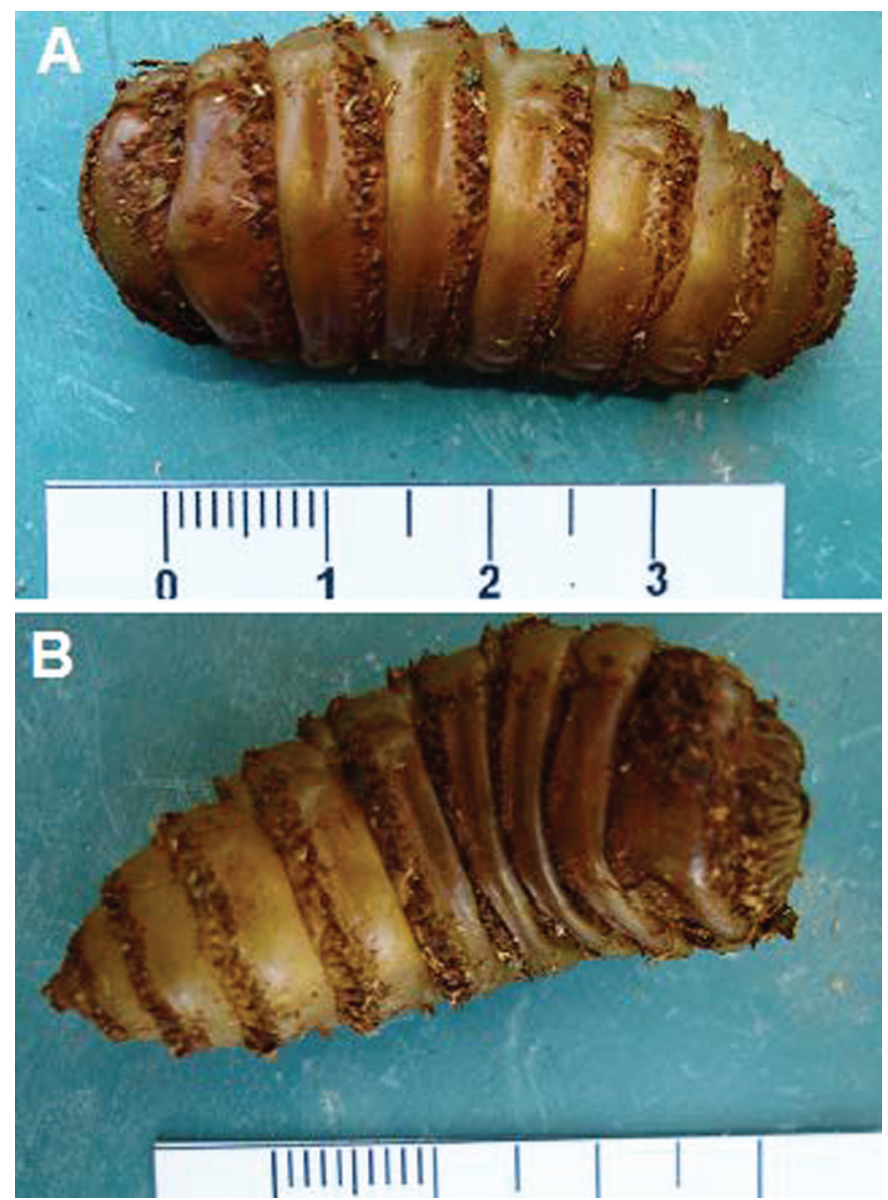

Fig.1. Dorsal (A) and ventral (B) aspects of a third-stage Gyrostigma rhinocerontis larva (Diptera: Oestridae, Gasterophilinae), found in recently-defecated feces by a white rhino (Ceratotherium simum) imported from South Africa. Itatiba, São Paulo, Brazil, 2005. Source: Developed by the authors.

cause insignificant clinical signs. Gyrostigma larvae have also been found in the Northern hemisphere, in the feces of imported rhinos, apparently without completing the evolution cycle, and natural infections by this parasite have not been observed outside the African continent (Silberman \& Fulton 1979, Griner 1983).

In Brazil, Brum et al. (1996) are responsible for the only previous report of finding Gyrostigma larvae in the feces of a white rhino originating from South Africa, kept in captivity in the Zoo at Sapucaia do Sul - RS. In that case, some larvae were cultivated in vials containing damp sawdust in order to estimate the pupa period, and the identification was based in specific taxonomic keys for adults and larvae. Due to the morphological characteristics in the development stages and based on the taxonomic data available, the parasite was identified as G. pavesii Corti, 1895. Comparing those larvae obtained in the feces of rhinos with Gasterophilus nasalis larvae, a species of the same family that is parasite to equine and common in Brazil, the latter measured 1.1 to $1.7 \mathrm{~cm}$, while those of G. pavesii reached 2.7 to $4.0 \mathrm{~cm}$. The pupal period at $25-33^{\circ} \mathrm{C}$ was of $34-35$ days, also longer than the pupal period for G. nasalis, which is of 23 to 28 days (Brum et al. 1996). 
From the finding of larvae, and aiming to treat the occurrence of an exotic parasitic insect, immediate measures were taken to control and eradicate this parasite, two of them considered as fundamental.

The animals received an anti-parasitic medication ${ }^{4}$ originally indicated for horses, in the form of a paste based on fenbendazole and trichlorfon. The product was given orally, in a mixture with the rhino food, with doses calculated by inter-specific allometric extrapolation (Pachaly \& Brito 2001) using the traditional fenbendazole recommendation of $7.5 \mathrm{mg} / \mathrm{kg}$ for a $500-\mathrm{kg}$ domestic horse as a model. The medication was given for three days, mixed to the food served to each animal, and the same treatment was repeated after 15 days.

For control and eradication of larvae in the animal feces there was indicated a daily environmental treatment for 30 days. The fecal material collected from the enclosure floor was transported in a trailer towed by a tractor and stored in a 5-meter deep septic tank. Systematically, before unloading the material, a layer of quicklime was applied over the tank, and after the unloading and leveling of the feces, a new layer was applied over them. Finishing the daily procedure, the septic tank was covered with a black plastic sheet.

With the drug treatment and environmental handling of feces, along the time the larvae were gradually not being observed anymore in the rhino feces, until they completely disappeared. The enclosure and its surroundings were carefully observed during at least two years following the first finding of larvae, and no signs of their presence were found.

The rhinos never showed any signs of disease related to the parasite and presented normal physical development, reaching adult age in a healthy state. At the time this report was written, in mid-2014, the information is that all of them are in good health conditions.

Similar to other wild species, the efforts for preserving rhinos include their breading and maintenance in captivity, in zoos throughout the world. Success, therefore, depends on several factors, including the maximum biomedical knowledge as possible. On the other hand, globalization, affecting several sectors in modern society, enables the international and intercontinental transit of wild animals. Unfortunately, many times this takes place without concomitant practice of strict zoo-sanitary measures, based in prior studies on the potential problems brought on by several species. In Brazil, considering the environmental conditions, many of these agents, such as parasites and others, can be able to adapt and eventually cause damage to the animal sanity, after it has been settled in our country.

Acknowledgements.- To the people who worked with the authors at the zoo during the study, João Caldas Filho and Odair José Ferreira (zookeepers), and Sérgio Rangel (biologist). To the Universidade Paranaense (Unipar) for granting part of this study.

\section{REFERENCES}

Barraclough D.A. 2006. Bushels of bots. J. Eur. Mosq. Control Assoc., London, 115:18-21.

Brum J.G.W., Valente A., Costa P.R.P., Giacomini C. \& Bohrer J.L. 1996. Gyrostigma pavesii (Diptera: Gasterophilidae) em rinoceronte (Ceratotherium simum) proveniente da África do Sul. Revta Bras. Parasitol. Vet. 5:57-58.

Evenhuis N.L. 2012. Sir Richard Owen's fly, Gyrostigma rhinocerontis (Diptera: Oestridae): correction of the authorship and date, with a list of animal names newly proposed by Owen in his little-known 1830 catalogue. Zootaxa, Auckland, 3501:74-82.

Griner L.A. 1983. Pathology of Zoo Animals. Zoological Society of San Diego, New York, p.484.

Gunn A. \& Pitt S.J. 2012. Parasitology: an integrated approach. Wiley-Blackwell, Oxford, p.173-442.

Lang E.M. 1983. Rhinoceroses, p.194. In: Klos E.M. \& Lang E. (Eds), Handbook of Zoo Medicine. Van Nostrand Reinhold, New York.

Miller E.R. 2003. Rhinoceridae (Rhinoceroses), p.558-569. In: Fowler M.E. \& Miller E.R. (Eds), Zoo and Wild Animal Medicine. 5th ed. W.B. Saunders, St Louis.

NHM 2014. Natural History Museum. Disponível em <http://www.nhm. ac.uk/print-version/?p=/nature-online/species-of-the-day/biodiversity/endangered-species/gyrostigmarhinocerontis/taxonomy/index. html> Accessed on August 25, 2014.

Nelson L. \& Fowler M.E. 1986. Rhinocerotidae, p.934-938. In: Fowler M.E. (Ed.), Zoo and Wild Animal Medicine. Vol.2. W.B. Saunders, Philadelphia.

Pachaly J.R. \& Brito H.F.V. 2001. Interspecific allometric scaling, p.475481. In: Fowler M.E. \& Cubas Z.S. (Eds), Biology, Medicine, and Surgery of South American Wild Animals. Iowa State University Press, Ames. $536 \mathrm{p}$.

Ramsay E.C. \& Zainuddin Z.Z. 1993. Infectious diseases of the rhinoceros and tapir, p.466-469. In: Fowler M.E. (Ed.), Zoo and Wild Animal Medicine. Vol.3. W.B. Saunders, Philadelphia.

Silberman M.S. \& Fulton R.B. 1979. Medical problems of captive and wild rhinoceros: a review of the literature and personal experiences. J. Zoo Anim. Med. 10:6.

Zumpt F. 1965. Myiasis in Man and Animals in the Old World. Butterworld, London. 267p.

${ }^{4}$ Fedaben ${ }^{\circledR}$ Paste, Lab. Fagra S.A., São Paulo, SP. 